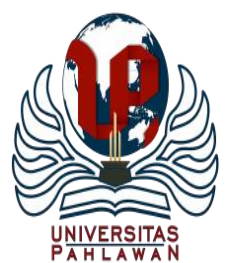

Edukatif : Jurnal Ilmu Pendidikan Volume 3 Nomor 5 Tahun 2021 Halm 3090 - 3104

EDUKATIF: JURNAL ILMU PENDIDIKAN

Research \& Learning in Education

https://edukatif.org/index.php/edukatif/index

\title{
Analisis Gaya Bahasa Pidato Bupati Karawang dalam Topik Imbauan serta Rekomendasinya sebagai Materi Pembelajaran Teks Pidato Di MTs
}

\author{
Mimin Widyaningsih ${ }^{1}{ }^{凶}$, Hendra Setiawan $^{2}$, Ferina Meliasanti $^{3}$ \\ Universitas Singaperbangsa Karawang, Indonesia ${ }^{1,2,3}$ \\ E-mail : $\underline{\text { miminwidya2410@gmail.com }}{ }^{1}$, hendra.setiawan@fkip.unsika.ac.id ${ }^{2}$, \\ ferina.meliasanti@fkip.unsika.ac.id ${ }^{3}$
}

\begin{abstract}
Abstrak
Penelitian ini dilatarbelakangi oleh penggunaan gaya bahasa, jenis gaya bahasa, fungsi gaya bahasa, tujuan digunakan gaya bahasa, serta kemampuan menulis teks pidato pada siswa di tingkat SLTP terkait pidato Bupati Karawang. Sehingga tujuan dalam penelitian ini untuk mendeskripsikan gaya bahasa Bupati Karawang dalam topik imbauan, serta mendeskripsikan bentuk rekomendasi hasil analisis gaya bahasa pidato Bupati Karawang terhadap pembelajaran teks pidato di MTs. Pendekatan penelitian menggunakan pendekatan kualitatif. Dalam mengetahui fenomena ini, maka dapat dperoleh dengan cara menganalisis, mendeskripsikan, dan mengeksplorasi hasil penelitian gaya bahasa pidato Bupati Karawang ke dalam bentuk narasi yang dideskripsikan. Hasil penelitian yang diperoleh, terdapat 35 tuturan mengandung gaya bahasa yang dianalisis menggunakan teori Keraf (2009) dan Tarigan (2013) sebagai alat penentu untuk menganalisis data.
\end{abstract}

Kata Kunci: Gaya Bahasa, Pembelajaran Teks Pidato.

\section{Abstract}

This research is motivated by the use of language style, type of language style, function of language style, the purpose of using language style, and the ability to write speech texts for students at the junior high school level related to the speech of the Regent of Karawang. So that the purpose of this study is to describe the language style of the Regent of Karawang in the topic of appeal, and to describe the form of recommendation from the analysis of the style of speech by the Regent of Karawang towards the learning of speech texts in MTs. The research approach uses a qualitative approach. In knowing this phenomenon, it can be obtained by analyzing, describing, and exploring the results of the research on the Karawang Regent's speech style in the form of a described narrative. The results obtained, there are 35 utterances containing language styles which were analyzed using the theory of Keraf (2009) and Tarigan (2013) as a determining tool for analyzing data.

Keywords: Language style, speech texts learning.

Copyright (c) 2021 Mimin Widyaningsih, Hendra Setiawan, Ferina Meliasanti

$\triangle$ Corresponding author

Email : miminwidya2410@ gmail.com

DOI : https://doi.org/10.31004/edukatif.v3i5.1208

ISSN 2656-8063 (Media Cetak)

ISSN 2656-8071 (Media Online) 
3091 Analisis Gaya Bahasa Pidato Bupati Karawang dalam Topik Imbauan serta Rekomendasinya sebagai Materi Pembelajaran Teks Pidato Di MTs - Mimin Widyaningsih, Hendra Setiawan, Ferina Meliasanti DOI: https://doi.org/10.31004/edukatif.v3i5.1208

\section{PENDAHULUAN}

Bahasa merupakan sarana bagi makhluk hidup untuk dapat berinteraksi dengan makhluk hidup lainnya. Setiap manusia memiliki ciri khas dalam berbahasa, seperti ciri khas dalam penyampaian, logat, ataupun gaya bahasa. Ciri khas gaya bahasa manusia tentunya berbeda-beda dan beragam. Namun, sebagai makhluk sosial seharusnya bahasa yang kita sampaikan kepada orang lain harus dapat dipahami. Gaya dalam berbahasa merupakan modal utama seseorang dalam menyampaikan ide, gagasan, atau maksud kepada orang lain. Gaya bahasa juga dapat digunakan sebagai pemikat atau daya tarik seseorang dalam mengindahkan tuturan bahasa yang digunakan. Maka dari itu, sebagai makhluk sosial tentunya harus mampu menyampaikan gagasan menggunakan gaya bahasa yang baik dan dimengerti oleh orang lain.

Gaya bahasa dijadikan sebagai kemampuan penyampaian gagasan seseorang yang sangat berpengaruh dalam penggunaan kata, susunan kalimat, atau estetika kalimatnya. Gagasan seseorang pun terdapat juga dalam pidato, karena pidato merupakan bentuk kegiatan berbahasa lisan di depan umum untuk menyampaikan pendapat, harapan, dan tujuan tertentu. Dalam penyampaian, seseorang harus memiliki kemampuan berbicara yang harus diimbangi dengan pengetahuan dan latihan. Seseorang yang terbiasa berpidato bisa dengan mudah menguasai pendengar dalam menyampaikan ide-idenya agar dapat diterima oleh orang lain. Kemahiran dalam berpidato merupakan suatu hal yang sangat penting bagi para tokoh politisi atau pemimpin dengan tujuan memberikan pesan atau kesan untuk mencapai kepentingan di dalam suatu wilayah. Oleh sebab itu, berhasil atau tidaknya seseorang dalam berpidato tergantung pada pengetahuan, pemilihan kata yang cukup, dan memahami konsep materinya.

Penelitian yang dilakukan oleh Yucha Febria Kusumaningrum pada tahun 2014, dalam tesis yang berjudul "Analisis Kritis Teks Pidato Susilo Bambang Yudhoyono Terkait Kenaikan BBM Tahun 2012-2013". Penelitian tersebut bertujuan untuk mendeskripsikan makna interpersonal yang digunakan oleh presiden Susilo Bambang Yudhoyono atau lebih akrab dengan sebutan SBY, dalam pidato kepresidenan yang berkaitan dengan kebijakan kenaikan BBM selama era kabinet Indonesia Bersatu tahun 2009-2014 atau periode kedua kepemimpinan presiden SBY. Rencana kenaikan BBM tersebut terjadi pada tahun 2012 dan 2013. Tesis Yucha Febria Kusumaningrum sebagai peneliti menemukan pemarkah-pemarkah yang menunjukan makna interpersonal bahasa sesuai teori SFL dan menemukan ideologi dalam teks pidato presiden SBY.

Selanjutnya, penelitian yang disusun oleh Helniati Purangga pada tahun 2017 yang berjudul "Penggunaan Gaya Bahasa Mario Teguh dalam Instagram". Skripsi tersebut mendeskripsikan gaya bahasa, jenis, wujud, dan makna gaya bahasa yang terdapat dalam instagram Mario Teguh. Dalam penelitian tersebut disimpulkan bahwa gaya bahasa yang digunakan Mario Teguh dalam instagram meliputi gaya bahasa perumpaaan, metafora, personifikasi, antitesis, hiperbola, klimaks, sitire, alusi, erotis, asonansi, kiasmus, epizeukis, epistrofa, dan anaphora. Selain itu, penelitian oleh Moch. Ferdy Ardiansyah pada tahun 2017, yang berjudul "Analisis Retorika Basuki Tjahaja Purnama dalam Kampanye Rakyat Pemilihan Kepala Daerah Khusus Ibu Kota Jakarta di Rumah Lembang 2017 (Kajian Retorika Aristoteles)”. Penelitian skripsi tersebut bersifat deskriptif kualitatif, pengumpulan data dilakukan dengan teknik catat, sedangkan analisis menggunaka metode deskriptif analisis dengan menggunakan teknik analisis teks. Skripsi Moch. Ferdy Ardiansyah dikaji dengan teori dari Aristoteles yakni lima hukum retorika (The Five Canons of Retoric). Berdasarkan hasil penelitiannya, bahwa retorika BTP yang merujuk pada pidato-pidatonya saat kampanye di Rumah Lembang terbukti menggunakan hokum retorika yang dikemukakan Aristoteles. Lima hokum tersebut yakni: invention (penemuann), dispostio (penyusunan), elucutio (gaya), memoria (ingatan), dan pronontitio (penyampaian).

Pada penelitian ini, dipilih dr. Cellica Nurachadiana sebagai Bupati Karawang menjadi subjek penelitian didasari oleh kesederhanaan dan kelugasan berbahasa serta jarang menggunakan pemilihan kata yang sulit dimengerti oleh orang lain. Dalam menyampaikan pidatonya, Bupati Karawang terkesan santai dan 
3092 Analisis Gaya Bahasa Pidato Bupati Karawang dalam Topik Imbauan serta Rekomendasinya sebagai Materi Pembelajaran Teks Pidato Di MTs - Mimin Widyaningsih, Hendra Setiawan, Ferina Meliasanti DOI: https://doi.org/10.31004/edukatif.v3i5.1208

lugas. Namun, meski terkesan santai, ketegasan sangat terlihat dari gerak-gerik ketika berbicara sebagai seorang bupati yang punya wewenang dalam mengelola pemerintahan. Pidato resmi yang dilakukan oleh Bupati Karawang biasanya menggunakan teks yang telah disiapkan berupa poin-poin pentingnya saja.

Berdasarkan latar belakang tersebut, dilakukan analisis terkait gaya bahasa yang digunakan Bupati Karawang dalam penyampaian pidato. Maka, dengan judul penelitian "Analisis Gaya Bahasa Pidato Bupati Karawang dalam Topik Imbauan serta Rekomendasinya sebagai Materi Pembelajaran Teks Pidato di MTs" menarik untuk diteliti karena untuk mengetahui jenis gaya bahasa berdasarkan pengucapan langsung dalam pidato Bupati Karawang yang telah direkam oleh penulis. Dengan demikian, penulis merekomendasikan mengenai Pembelajaran Jarak Jauh (PJJ) terkait gaya bahasa dalam berpidato dengan materi pembelajaran pada siswa di Madrasah Tsanawiyah (MTs) berupa teks pidato persuasif dalam pembelajaran Bahasa Indonesia dengan menggunakan aplikasi WhatsApp. Rekomendasi hasil penelitian ini bertujuan untuk lebih memperhatikan penulisan bahasa yang sesuai dengan Pedoman Umum Ejaan Bahasa Indonesia (FUEBI) dan Kamus Besar Bahasa Indonesia (KBBI) agar dapat melakukan penulisan teks pidato yang baik dan benar, sehingga pembelajaran teks pidato tersebut menjadi sesuai dan terarah.

\section{METODE PENELITIAN}

Penelitian ini menggunakan metode kualitatif deskriptif, data yang dianalisis bukan berupa angkaangka (data kualitatif), berupa kata-kata. Subjek dalam penelitian ini adalah Bupati Karawang sebagai informan yang memberikan manfaat terkait pidatonya. Selain itu, proses penelitian kualitatif akan dapat diketahui setelah memasuki objek, dengan cara membaca informasi tertulis, gambar-gambar, berpikir, dan melihat objek dan aktivitas orang yang ada di sekelilingnya, melakukan wawancara dan sebagainya. Meskipun penelitian kualitatif belum memiliki masalah yang jelas, akan tetapi penulis dapat langsung memasuki objek di yang diteliti. Adapun objek penelitian ini adalah gaya bahasa pidato Bupati Karawang dalam topik imbauan.

Instrumen dalam penelitian ini adalah peneliti sendiri (human instrument), karenanya peneliti merupakan alat yang menentukan fokus penelitian, objek dan subjek penelitian, metodologi penelitian, serta mencari data dan sumber data. Maka dari itu, peneliti juga yang mengumpulkan data, menilai kualitas data, dan menganalisis data itu sendiri.

Peneliti menspesifikasikan penelitian ini menggunakan teknik pengumpulan data berupa dokumen resmi. Terdapat dua macam dokumen resmi yaitu dokumen internal dan dokumen eksternal. Dokumen internal meliputi memo, pengumuman, instruksi, aturan, rekaman hasil rapat, dan keputusan Bupati Karawang terkait topik imbauan. Adapun dokumen eksternal berupa bahan-bahan informasi yang dihasilkan oleh lembaga sosial, misalnya seperti majalah, buletin, pernyataan dan berita yang disiarkan melalui media massa. Maka dari itu, teknik pengumpulan data yang selanjutnya akan digunakan dalam penelitian ini teknik dokumentasi dalam penelitian ini dilakukan dengan merekam kegiatan pidato Bupati Karawang dalam topik imbauan.

Dalam penelitian ini, dilakukan dengan observasi pastisipatif pasif. Penulis melakukan observasi dan terlibat secara pasif dengan kegiatan subjek atau orang yang sedang diamati sebagai sumber data penelitian. Dengan melakukan observasi partisipan ini, maka data yang akan diperoleh menjadi lebih lengkap, tajam, dan sampai mengetahui lebih dalam tingkat makna dari setiap perilaku dan gaya bahasa yang nampak. Oleh sebab itu, dalam hal ini penulis datang di tempat kegiatan orang yang diamati, tetapi tidak ikut terlibat dalam kegiatan tersebut.

Adapun, teknik analisis data yang digunakan dalam penelitian ini, antara lain: mengumpulkan data informasi berupa rekaman video yang dibutuhkan terkait pidato Bupati Karawang, menyimak hasil rekaman video yang telah direkam oleh peneliti terkait pidato Bupati Karawang dalam imbauan, mentranskripsikan hasil rekaman video pidato Bupati Karawang ke dalam bentuk catatan peneliti, mendeskripsikan hasil analisis 
3093 Analisis Gaya Bahasa Pidato Bupati Karawang dalam Topik Imbauan serta Rekomendasinya sebagai Materi Pembelajaran Teks Pidato Di MTs - Mimin Widyaningsih, Hendra Setiawan, Ferina Meliasanti DOI: https://doi.org/10.31004/edukatif.v3i5.1208

gaya bahasa pidato Bupati Karawang dalam bentuk uraian yang bersifat deskriptif, merekomendasikan hasil analisis gaya bahasa pidato Bupati Karawang dengan pembelajaran teks pidato di sekolah, dan menyimpulkan hasil penelitian. Simpulan dari hasil analisis data tersebut menjadi hasil penelitian.

\section{HASIL DAN PEMBAHASAN PENELITIAN}

Data yang dijadikan sebagai bahan analisis ini merupakan pidato atau sambutan dari dr. Cellica Nurachaddiana sebagai Bupati Karawang dalam kegiatan penyerahan bantuan alat dan mesin pertanian Rice Milling Unit $(R M U)$ dan sapi dari Kementerian Pertanian. Pidato tersebut bertempat di Dinas Pertanian Kabupaten Karawang, dituturkan dengan lantang oleh Cellica dengan membawa catatan kecil sebagai poin inti dari pidato atau sambutan yang disampaikan. Pidato tersebut dilaksanakan pada hari Kamis, 10 Juni 2021 bertempat di Dinas Pertanian Kabupaten Karawang. Penggunaan gaya bahasa yang digunakan oleh dr. Cellica Nurrachadiana menggandung beberapa gaya Dengan demikian, untuk memperjelas adanya beberapa gaya bahasa yang tergolong dalam gaya bahasa pertautan dijelaskan sebagai berikut.

\section{Metonimia}

Terdapat satu gaya bahasa metonimia dalam pidato Bupati Karawang. Penulis menjelaskan secara rinci atau memaparkan lebih dalam hasil analisis agar lebih dipahami. Adapun tuturan kalimat gaya bahasa metonimia sebagai berikut.

Tuturan "Yang kami hormati, izinkan untuk menyebutkan terlebih dahulu, karena yang menjadi fasilitator buat kita semua".

Pada data (1) kalimat tersebut dituturkan oleh Bupati Karawang termasuk ke dalam gaya bahasa metonimia. Hal tersebut terdapat satu kata yang memperkuat yaitu "fasilitator". Kata "fasilitator" dapat diartikan orang yang bertugas sebagai penyedia atau menyediakan fasilitas. Dengan begitu, bisa dikatakan dalam gaya bahasa metonimia terdapat pada "menjadi fasilitator buat kita semua" termasuk dalam gaya bahasa yang berkaitan erat dengan suatu hal dengan memaknai kata lain yang punya keterkaitan sebagai penggantinya. Dalam hal ini, mempunyai makna yang merujuk atau tertuju kepada anggota dalam bidang kepemerintahan harus senantiasa menjadi penyedia fasilitas untuk masyarakat.

\section{Eufemisme}

Terdapat empat gaya bahasa eufemisme dalam pidato Bupati Karawang. Penulis menjelaskan secara rinci atau memaparkan lebih dalam hasil analisis agar lebih dipahami. Adapun tuturan kalimat gaya bahasa eufemisme sebagai berikut.

1) Tuturan "Supaya si alat itu bergerak terus dan menghasilkan uang."

Pada data (2) tersebut dituturkan oleh Bupati Karawang termasuk ke dalam gaya bahasa eufemisme. Hal tersebut terdapat beberapa frasa yang memperkuat yaitu "si alat" dan "menghasilkan uang". Frasa "si alat" dapat diartikan sebagai alat yang dipakai untuk mengerjakan sesuatu. Sedangkan frasa "menghasilkan uang" merupakan salah satu kata kerja yang bertujuan untuk mengeluarkan dan menjadikan hasil yang berupa uang.

Dengan begitu, dapat dikatakan dalam gaya bahasa eufemisme memiliki arti bahwa gaya bahasa ini yang memperhalus untuk menunjukan suatu kesopanan. Dalam hal ini, tuturan "Supaya si alat itu bergerak terus dan menghasilkan uang", mempunyai makna yang merujuk atau tertuju pada beberapa bantuan berupa alat pertanian. Alat tersebut diterima dari Bapak Haerudin Amin, Komisi IV DPR RI, agar para petani memanfaatkan alatnya untuk usaha sehingga bisa menjadi alat untuk membantu para petani dalam mencari penghasilan.

2) Tuturan "Jaga, jaga baik-baik bantuannya, nanti jaminannya dikasih lebih." 
Pada data (3) tersebut dituturkan oleh Bupati Karawang termasuk ke dalam gaya bahasa eufemisme. Dapat dikatakan dalam gaya bahasa eufemisme karena menjelaskan suatu bagian yang penting dalam suatu hal untuk memperhalus serta menunjukan suatu kesopanan. Terdapat dua frasa yang menjadi penguat tuturan tersebut termasuk ke dalam gaya bahasa eufemisme yaitu frasa "bantuannya" dan "jaminannya". Dalam hal ini, tuturan "Jaga, jaga baik-baik bantuannya, nanti jaminannya dikasih lebih" mempunyai makna yang terkandung terkait masyarakat yang diberi bantuan berupa alat pertanian. Alat tersebut harus dijaga, digunakan, dan dirawat sehingga akan mendapatkan tanggungan dari pemerintah atas pemberian alat pertanian yang diterima oleh penerima bantuan. Adapun jaminan dari pemerintah berupa perbaikan alat (service) apabila alat tersebut mengalami kerusakan.

3) Tuturan "Minta aspirasi dari Komisi IV untuk nanti melalui rekomendasi dari dinas, karena semua aspirasi atau semua usulan harus melalui dinas, karena para petani kami harus terdaftar di dinas kami."

Pada data (4) tersebut dituturkan oleh Bupati Karawang termasuk ke dalam gaya bahasa eufemisme. Hal ini menjelaskan suatu bagian yang penting dalam suatu hal untuk memperhalus serta menunjukan suatu kesopanan. Selain itu, gaya bahasa eufemisme juga merupakan gaya bahasa yang memiliki tujuan yang baik dengan ungkapan yang tidak menyinggung perasaan orang lain. Dalam hal ini, tuturan "Minta aspirasi dari Komisi IV untuk nanti melalui rekomendasi dari dinas, karena semua aspirasi atau semua usulan harus melalui dinas, karena para petani kami harus terdaftar di dinas kami." mengandung makna bahwa Bupati Karawang menyarankan kepada Komisi IV harus mendengarkan saran, tanggapan, dan kritik dari para petani. Setelah itu, harus melakukan koordinasi dengan semua elemen Dinas Pertanian dan Pemda (Pemerintah Daerah), sehingga para petani akan terdaftar di Dinas Pertanian dan dipantau langsung oleh pihak dinas.

4) "Tuturan "Beberapa waktu yang lalu, kita kurang lebih tujuh ratus juta, Kang. Tapi, karena memang rawan bencana, entah itu kebanjiran, entah itu hama, wereng, entah itu tikus, dan lain sebagainya. Minimal reugreug petani teh, yang namanya bencana kita enggak tahu."

Pada data (5) dituturkan oleh Bupati Karawang termasuk ke dalam gaya bahasa eufemisme karena secara tidak langsung mengungkapkan suatu hal yang benar-benar terjadi berdasarkan adanya peristiwa yang diketahui bersama serta menggantikan kata-kata yang dianggap kasar atau kurang pantas diungkapkan. Gaya bahasa ini pun, hubungannya erat dengan nilai sosial. Dapat dibuktikan pada data "Beberapa waktu yang lalu, kita kurang lebih tujuh ratus juta, Kang. Tapi, karena memang ada rawan bencana, entah itu kebanjiran, entah itu hama, wereng, entah itu tikus, dan lain sebagainya. Minimal reugreug petani teh, yang namanya bencana kita enggak tahu." bahwa Bupati Karawang menuturkan "rawan bencana" untuk mengganti kata "bahaya" atau "gawat" yang menimbulkan gangguan keamanan masyarakat. Selain itu yang makna yang terkandung dalam data tersebut, Bupati Karawang menjelaskan terkait bencana yang pernah menimpa para petani Karawang pada beberapa waktu lalu.

\section{Eufemisme}

Terdapat empat gaya bahasa antonomasia dalam pidato Bupati Karawang. Penulis menjelaskan secara rinci atau memaparkan lebih dalam hasil analisis agar lebih dipahami. Adapun tuturan kalimat gaya bahasa antonomasia sebagai berikut.

1) Tuturan "Ternyata persoalan ketika Elsintan dibangun, saya harap Bupati menjaga Elshintannya."

Pada data (5) dituturkan oleh Bupati Karawang termasuk ke dalam gaya bahasa antonomasia karena terdapat kata "Bupati" dalam data tersebut. Dalam gaya bahasa antonomasia, seseor ang diberi julukan, jabatan, serta gelar tertentu yang memiliki ciri khas. Dalam kehidupan bermasyarakat, sesekali orang dipanggil dengan julukannya. Dapat dibuktikan pada data "Ternyata persoalan ketika Elsintan dibangun, saya harap Bupati menjaga Elshintannya”, mengandung makna bahwasannya ketika membahas terkait Elsintan 
3095 Analisis Gaya Bahasa Pidato Bupati Karawang dalam Topik Imbauan serta Rekomendasinya sebagai Materi Pembelajaran Teks Pidato Di MTs - Mimin Widyaningsih, Hendra Setiawan, Ferina Meliasanti DOI: https://doi.org/10.31004/edukatif.v3i5.1208

pertanian, ada masyarakat memanggil dr. Cellica Nurachaddiana dengan panggilan "Bupati" sehingga dapat menggantikan nama diri.

2) Tuturan "Yang kami hormati, yang hadir Pak Asisten bersama saya"

Pada data (6) dituturkan oleh Bupati Karawang termasuk ke dalam gaya bahasa antonomasia karena terdapat kata "Pak Asisten" dalam data tersebut. Dalam gaya bahasa antonomasia, seseorang diberi julukan, jabatan, serta gelar tertentu yang memiliki ciri khas. Dalam hal ini, data "Yang kami hormati, yang hadir Pak Asisten bersama saya" memiliki makna adanya panggilan yang menggantikan nama diri. Kata "Pak Asisten" merupakan sapaan dari dr. Cellica Nurachaddiana sebagai Bupati Karawang, yang berarti menyapa dan tertuju kepada Bapak Samsuri, S.IP. sebagai Asisten Daerah Kabupaten Karawang (Asda) yang menghadiri acara Penyerahan Bantuan Alat dan Mesin Pertanian Rice Miling Unit (RMU) dan Sapi di Dinas Pertanian.

3) Tuturan "Ibu Camat tadi hadir karena ada acara dengan para Lurah, beliau izin terlebih dahulu"

Pada data (7) dituturkan oleh Bupati Karawang termasuk ke dalam gaya bahasa antonomasia karena terdapat kata "Ibu Camat" dalam data tersebut. Dalam gaya bahasa antonomasia, seseorang diberi julukan, jabatan, serta gelar tertentu yang memiliki ciri khas. Dalam hal ini, data "Ibu Camat tadi hadir karena ada acara dengan para Lurah, beliau izin terlebih dahulu" memiliki makna adanya panggilan yang menggantikan nama diri. Kata "Ibu Camat" merupakan jabatan resmi. Dalam pidatonya, dr. Cellica Nurachaddiana sebagai Bupati Karawang yang berarti menyapa dan tertuju kepada Ibu Lasmini Ningrum sebagai Camat Karawang Barat yang izin terlebih dahulu untuk meninggalkan acara Penyerahan Bantuan Alat dan Mesin Pertanian Rice Miling Unit (RMU) dan Sapi di Dinas Pertanian.

4) Tuturan "Pak Kapolsek, Pak Danramil, yang sangat saya cintai para Kelompok Tani, yang Insyaallah kita semua dirahmati oleh Allah Swt"

Pada data (8) dituturkan oleh Bupati Karawang termasuk ke dalam gaya bahasa antonomasia karena terdapat kata "Pak Kapolsek" dan "Pak Danramil" dalam data tersebut. Dalam gaya bahasa antonomasia, seseorang diberi julukan, jabatan, serta gelar tertentu yang memiliki ciri khas. Dalam hal ini, data "Pak Kapolsek, Pak Danramil, yang sangat saya cintai para Kelompok Tani, yang Insyaallah kita semua dirahmati oleh Allah Swt" memiliki makna adanya panggilan yang menggantikan nama diri. Kata "Pak Kapolsek" dan "Pak Danramil" merupakan jabatan resmi. Dalam pidatonya, dr. Cellica Nurachaddiana sebagai Bupati Karawang, yang berarti menyapa dan tertuju kepada Bapak Kapten Inf Suryadi sebagai Danramil (Komandan Rayon Militer) di Koramil 0401 Karawang dan Bapak Kompol Suparno, S.H. sebagai Kapolsek Karawang Kota. Dalam hal ini, pada ada saat itu berada bersamaan dengan Bupati Karawang dalam menghadiri acara Penyerahan Bantuan Alat dan Mesin Pertanian Rice Miling Unit (RMU) dan Sapi di Dinas Pertanian.

\section{Erotesis}

Terdapat tujuh gaya bahasa erotesis dalam pidato Bupati Karawang. Penulis menjelaskan secara rinci atau memaparkan lebih dalam hasil analisis agar lebih dipahami. Adapun tuturan kalimat gaya bahasa erotesis sebagai berikut.

1) Tuturan "Bikin kelompok yang besar, terus teman-teman gimana nanti caranya ngider terus, benar enggak? Supaya si alat itu bergerak terus dan menghasilkan uang. Sepakat?"

Pada data (9) dituturkan oleh Bupati Karawang termasuk ke dalam gaya bahasa erotesis karena mengandung semacam pertanyaan yang digunakan dalam pidato dengan bertujuan untuk mencapai pengaruh yang lebih dalam serta penekanan yang wajar dan sama sekali memerlukan satu jawaban yang mungkin. Data "Bikin kelompok yang besar, terus teman-teman gimana nanti caranya ngider terus, benar enggak? Supaya si alat itu bergerak terus dan menghasilkan uang. Sepakat?" memiliki makna bahwa pertanyaan tersebut tidak perlu sebuah jawaban yang harus diberikan pada saat pidato itu berlangsung. Sebenarnya pertanyaan tersebut sudah diketahui oleh para tamu yang menghadiri acara Penyerahan Bantuan Alat dan Mesin Pertanian 
3096 Analisis Gaya Bahasa Pidato Bupati Karawang dalam Topik Imbauan serta Rekomendasinya sebagai Materi Pembelajaran Teks Pidato Di MTs - Mimin Widyaningsih, Hendra Setiawan, Ferina Meliasanti DOI: https://doi.org/10.31004/edukatif.v3i5.1208

Rice Miling Unit (RMU) dan Sapi di Dinas Pertanian, bahwasanya alat yang didapat bisa mendorong dan digunakan alat bantu dalam bertani sehingga bisa menghasilkan uang.

2) Tuturan "Karena kalau diam terus ngajugrug, Cuma udah panen diem, sudah. Nunggu lagi enam bulan. Kalau rusak, bingung benerin laginya di mana. Bener gak?"

Pada data (10) dituturkan oleh Bupati Karawang termasuk ke dalam gaya bahasa erotesis karena mengandung semacam pertanyaan yang digunakan dalam pidato dengan bertujuan untuk mencapai pengaruh yang lebih dalam serta penekanan yang wajar dan sama sekali memerlukan satu jawaban yang mungkin. Data "Karena kalau diam terus ngajugrug, Cuma udah panen diem, sudah. Nunggu lagi enam bulan. Kalau rusak, bingung benerin laginya di mana. Bener gak?" memiliki makna bahwa pertanyaan tersebut tidak perlu sebuah jawaban yang harus diberikan pada saat pidato itu berlangsung. Sebenarnya pertanyaan tersebut sudah diketahui oleh para tamu yang menghadiri acara Penyerahan Bantuan Alat dan Mesin Pertanian Rice Miling Unit (RMU) dan Sapi di Dinas Pertanian, bahwasanya kalau alat tersebut tidak digunakan sebagaimana mestinya, kalau ada kerusakan para petani bingung cara memperbaikinya.

3) Tuturan "Makanya saya perlu kerja sama, Pak Hanafi, Pak Kadarisman, teman-teman dinas, tugasnya adalah membentuk semua UPJA-UPJA yang ada di Kabupaten Karawang, semua yang dapat bantuan ini dibentuklah UPJA-UPJAnya. Benar enggak, Kang?"

Pada data (11) dituturkan oleh Bupati Karawang termasuk ke dalam gaya bahasa erotesis karena mengandung semacam pertanyaan yang digunakan dalam pidato dengan bertujuan untuk mencapai pengaruh yang lebih dalam serta penekanan yang wajar dan sama sekali memerlukan satu jawaban yang mungkin. Data "Makanya saya perlu kerja sama, Pak Hanafi, Pak Kadarisman, teman- teman dinas, tugasnya adalah membentuk semua UPJA-UPJA yang ada di Kabupaten Karawang, semua yang dapat bantuan ini dibentuklah UPJA-UPJAnya. Benar enggak, Kang?" memiliki makna bahwa pertanyaan tersebut tidak perlu sebuah jawaban yang harus diberikan pada saat pidato itu berlangsung. Sebenarnya pertanyaan tersebut sudah diketahui oleh para tamu yang menghadiri acara Penyerahan Bantuan Alat dan Mesin Pertanian Rice Miling Unit (RMU) dan Sapi di Dinas Pertanian, bahwasanya perlu adanya kerja sama antar anggota pemerintah yang bekerja di Dinas Pertanian untuk membentuk UPJA yang ada di Kabupaten Karawang sehingga akan berjalan sebagaimana mestinya.

4) Tuturan "Manfaat yang bisa kita berikan kepada seluruh para petani yang ada di Karawang terus menyebar kebaikan. Benar enggak?"

Pada data (12) dituturkan oleh Bupati Karawang termasuk ke dalam gaya bahasa erotesis karena mengandung semacam pertanyaan yang digunakan dalam pidato dengan bertujuan untuk mencapai pengaruh yang lebih dalam serta penekanan yang wajar dan sama sekali memerlukan satu jawaban yang mungkin. Data "Manfaat yang bisa kita berikan kepada seluruh para petani yang ada di Karawang terus menyebar kebaikan. Benar enggak?" memiliki makna bahwa pertanyaan tersebut tidak perlu sebuah jawaban yang harus diberikan pada saat pidato itu berlangsung. Sebenarnya pertanyaannya sudah diketahui oleh para tamu yang menghadiri acara Penyerahan Bantuan Alat dan Mesin Pertanian Rice Miling Unit (RMU) dan Sapi di Dinas Pertanian, bahwasanya bertanya mengenai manfaat apa yang bisa diberikan kepada seluruh para petani yang ada di Kabupaten Karawang terus menyebar kebaikan. Dalam hal ini, berupa penggunaan alat sebagaimana mestinya, serta harus membagikan ilmu antar petani.

5) Tuturan "Udah mah kadang harga gabah kadang-kadang turun. Bener enggak?"

Pada data (13) dituturkan oleh Bupati Karawang termasuk ke dalam gaya bahasa erotesis karena mengandung semacam pertanyaan yang digunakan dalam pidato dengan bertujuan untuk mencapai pengaruh yang lebih dalam serta penekanan yang wajar dan sama sekali memerlukan satu jawaban yang mungkin. Data "Udah mah kadang harga gabah kadang-kadang turun. Bener enggak?" memiliki makna bahwa pertanyaan tersebut tidak perlu sebuah jawaban yang harus diberikan pada saat pidato itu berlangsung. Sebenarnya pertanyaannya sudah diketahui oleh para tamu yang menghadiri acara Penyerahan Bantuan Alat dan Mesin 
3097 Analisis Gaya Bahasa Pidato Bupati Karawang dalam Topik Imbauan serta Rekomendasinya sebagai Materi Pembelajaran Teks Pidato Di MTs - Mimin Widyaningsih, Hendra Setiawan, Ferina Meliasanti DOI: https://doi.org/10.31004/edukatif.v3i5.1208

Pertanian Rice Miling Unit (RMU) dan Sapi di Dinas Pertanian, bahwasanya membahas mengenai harga gabah sering terjadi penurunan yang terjadi pada para petani di Kabupaten Karawang.

6) Tuturan "Komo musim penghujan, harga merosot, PBB masih ditagih pemerintah daerah, keterlaluan pemerintah daerah kalau seperti itu. Bener enggak?"

Pada data (14) dituturkan oleh Bupati Karawang termasuk ke dalam gaya bahasa erotesis karena mengandung semacam pertanyaan yang digunakan dalam pidato dengan bertujuan untuk mencapai pengaruh yang lebih dalam serta penekanan yang wajar dan sama sekali memerlukan satu jawaban yang mungkin. Data "Komo musim penghujan, harga merosot, PBB masih ditagih pemerintah daerah, keterlaluan pemerintah daerah kalau seperti itu. Bener enggak?" memiliki makna bahwa pertanyaan tersebut tidak perlu sebuah jawaban yang harus diberikan pada saat pidato itu berlangsung. Sebenarnya pertanyaannya sudah diketahui oleh para tamu yang menghadiri acara Penyerahan Bantuan Alat dan Mesin Pertanian Rice Miling Unit (RMU) dan Sapi di Dinas Pertanian, bahwasanya membahas mengenai akibat dari musim penghujan harga gabah sering terjadi penurunan yang terjadi pada para petani di Kabupaten Karawang, serta diberatkan pula dalam masalah tagihan PBB dari pemerintah daerah.

7) Tuturan "Bagaimana mungkinkah mereka membeli hasil kita?"

Pada data (15) dituturkan oleh Bupati Karawang termasuk ke dalam gaya bahasa erotesis karena mengandung semacam pertanyaan yang digunakan dalam pidato dengan bertujuan untuk mencapai pengaruh yang lebih dalam serta penekanan yang wajar dan sama sekali memerlukan satu jawaban yang mungkin. Data "Bagaimana mungkinkah mereka membeli hasil kita?" memiliki makna bahwa pertanyaan tersebut tidak perlu sebuah jawaban yang harus diberikan pada saat pidato itu berlangsung. Sebenarnya pertanyaannya sudah diketahui oleh para tamu yang menghadiri acara Penyerahan Bantuan Alat dan Mesin Pertanian Rice Miling Unit (RMU) dan Sapi di Dinas Pertanian, bahwasanya membahas mengenai hasil panen para petani yang ada di Kabupaten Karawang, hasil panennya dibeli atau dalam hal ini bekerjasama dengan Bulog yang dinaungi oleh BUMN. Tujuannya agar paraa petani tidak terkukung oleh para oknum-oknum tengkulak.

\section{Paralelisme}

Terdapat enam gaya bahasa paralelisme dalam pidato Bupati Karawang. Penulis menjelaskan secara rinci atau memaparkan lebih dalam hasil analisis agar lebih dipahami. Adapun tuturan kalimat gaya bahasa paralelisme sebagai berikut.

1) Tuturan "Minta aspirasi dari Komisi IV untuk nanti melalui rekomendasi dari dinas, karena semua aspirasi atau semua usulan harus melalui dinas, karena para petani kami harus terdaftar di dinas kami."

Pada data (16) termasuk ke dalam gaya bahasa paralelisme karena data tersebut menggunakan bagianbagian kalimat yang mempunyai kesamaan struktur secara berturutan dan kalimat terakhir menggunakan kata sambung, sehingga kesamaan struktur yang digunakan itu secara berturutan membentuk sejajarnya struktur dan memperindah kalimat dalam tuturan yang digunakan. Dalam hal ini, adanya adanya kesamaan dan kesejajaran pola-pola tersebut mempermudah untuk menemukan gagasan yang disampaikan. Dapat dibuktikan pada tuturan "Minta aspirasi dari Komisi IV untuk nanti melalui rekomendasi dari dinas, karena semua aspirasi atau semua usulan harus melalui dinas, karena para petani kami harus terdaftar di dinas kami." bahwa kata "minta aspirasi", dan "semua aspirasi" mempertegas kalimat paralel tersebut, sehingga mengandung adanya pengulangan pola, juga menunjukkan adanya fungsi, penekanan, dan gagasan yang diungkapkan oleh Bupati Karawang. Tuturan tersebut tentu memperjelas gagasan yang dimaksud walau berupa kalimat yang kompleks dan panjang, karenanya gaya bahasa paralelisme memiliki keunggulan dalam tuturan tersebut. Adapun makna yang terkandung bahwasannya Bupati Karawang mengimbau kepada para anggota pemerintahan yang ikut serta hadir dalam acara Penyerahan Bantuan Alat dan Mesin Pertanian Rice Miling Unit (RMU) dan Sapi di Dinas Pertanian, harus melaksanakan tugas mereka dalam menanggapi usulan, saran, 
3098 Analisis Gaya Bahasa Pidato Bupati Karawang dalam Topik Imbauan serta Rekomendasinya sebagai Materi Pembelajaran Teks Pidato Di MTs - Mimin Widyaningsih, Hendra Setiawan, Ferina Meliasanti DOI: https://doi.org/10.31004/edukatif.v3i5.1208

tanggapan, serta aspirasi dari para petani. Aspirasi tersebut harus disampaikan kepada dinas agar semua para petani di Kabupaten Karawang yang membutuhkan bantuan terkait pertanian, nantinya bisa langsung ditanggapi dan terdaftar di Dinas Pertanian.

2) Tuturan "Tapi, kalau kebaikan ini kita sambungkan atau kita sumbang kepada kelompok tani, kelompok tani yang lain mudah-mudahan insyaAllah akan menjadi amal kebaikan buat bapak-ibu sekalian."

Pada data (17) termasuk ke dalam gaya bahasa paralelisme karena data tersebut menggunakan bagianbagian kalimat yang mempunyai kesamaan dan pengulangan kata secara berturutan, serta pada kalimat terakhir menggunakan kata sambung, sehingga kesamaan struktur yang digunakan itu secara berturutan membentuk sejajarnya struktur dan mempertegas kalimat dalam tuturan yang digunakan. Dalam hal ini, adanya kesamaan dan kesejajaran pola-pola tersebut mempermudah untuk menemukan gagasan yang disampaikan. Dapat dibuktikan pada tuturan "Tapi, kalau kebaikan ini kita sambungkan atau kita sumbang kepada kelompok tani, kelompok tani yang lain mudah-mudahan insyaAllah akan menjadi amal kebaikan buat bapak-ibu sekalian", mengandung pengulangan pola kata pada "kelompok tani", juga menunjukkan adanya fungsi, penekanan, dan gagasan dalam mempertegas kalimat paralel tersebut. Dengan demikian, akan memperjelas gagasan yang dimaksud, karenanya gaya bahasa paralelisme memiliki keunggulan dalam tuturan. Adapun makna dalam tuturan tersebut, bahwasannya Bupati Karawang berpesan kepada pihak Dinas Pertanian agar menyambungkan sumbangan untuk beberapa kelompok tani yang hadir dalam acara Penyerahan Bantuan Alat dan Mesin Pertanian Rice Miling Unit (RMU) dan Sapi di Dinas Pertanian. Tidak hanya itu, Bupati Karawang berpesan agar pihak dinas memperhatikan juga kelompok tani yang lain, sehingga akan menjadi amal kebaikan untuk semua orang.

3) Tuturan "Saya pengen menjawab, tapi saya menyambungkannya. Tolong dijaga Elsintannya. Ya, tolong dijaga Elsintannya".

Pada data (18) termasuk ke dalam gaya bahasa paralelisme karena data tersebut menggunakan bagianbagian kalimat yang mempunyai kesamaan dan pengulangan kata secara berturutan, serta pada kalimat terakhir menggunakan kata sambung, sehingga kesamaan struktur yang digunakan itu secara berturutan membentuk sejajarnya struktur dan mempertegas kalimat dalam tuturan yang digunakan. Dalam hal ini, adanya kesamaan dan kesejajaran pola-pola tersebut mempermudah untuk menemukan gagasan yang disampaikan. Dapat dibuktikan pada tuturan "Saya pengen menjawab, tapi saya menyambungkannya. Tolong dijaga Elsintannya. Ya, tolong dijaga Elsintannya." bahwa kata "menjawab", "menyambungkan", dan "tolong dijaga" mempertegas kalimat paralel, sehingga mengandung pengulangan pola, juga menunjukkan adanya fungsi, penekanan, dan gagasan yang dituturkan oleh Bupati Karawang.

Tuturan tersebut tentu memperjelas gagasan yang dimaksud, karenanya gaya bahasa paralelisme memiliki keunggulan dalam tuturan. Adapun makna yang terkandung bahwasannya Bupati Karawang menjawab dan menyambungkan pesan dari Bapak Haerudin Amin, Komisi IV DPR RI yang memberikan bantuan alat dan mesin pertanian Rice Miling Unit (RMU) dan sapi kepada beberapa kelompok tani yang ada di Kabupaten Karawang agar menjaga dan menggunakan alat serta bantuan ternak tersebut sebagai mana mestinya. Hal tersebut bertujuan agar bisa mempertanggungjawabkan kepada pihak pemberi bantuan.

4) Tuturan "Kalau besok misalnya traktornya rusak, combainnya rusak, pompanya rusak, kami yang akan memfasilitasi, kami yang akan menyediakan, untuk semua para petani Karawang."

Pada data (19) termasuk ke dalam gaya bahasa paralelisme karena data tersebut menggunakan bagianbagian kalimat yang mempunyai kesamaan dan pengulangan kata secara berturutan, serta pada kalimat terakhir menggunakan kata sambung, sehingga kesamaan struktur yang digunakan itu secara berturutan membentuk sejajarnya struktur dan mempertegas kalimat dalam tuturan yang digunakan. Dalam hal ini, adanya kesamaan dan kesejajaran pola-pola tersebut mempermudah untuk menemukan gagasan yang disampaikan. Dapat dibuktikan pada tuturan "Kalau besok misalnya traktornya rusak, combainnya rusak, 
3099 Analisis Gaya Bahasa Pidato Bupati Karawang dalam Topik Imbauan serta Rekomendasinya sebagai Materi Pembelajaran Teks Pidato Di MTs - Mimin Widyaningsih, Hendra Setiawan, Ferina Meliasanti DOI: https://doi.org/10.31004/edukatif.v3i5.1208

pompanya rusak, kami yang akan memfasilitasi, kami yang akan menyediakan, untuk semua para petani Karawang." bahwa terjadi pengulangan pada kata "kita".

Selain itu, kata "memfasilitasi" dan kata "menyediakan" mempertegas kalimat paralel tersebut, sehingga mengandung pengulangan pola, juga menunjukkan adanya fungsi yang sama, serta adanya kesamaan penekanan kata yang dituturkan oleh Bupati Karawang. Tuturan tersebut mengandung makna bahwa Bupati Karawang berumpama jika terjadi kerusakan pada alat bantuan pertanian seperti traktor, pompa, dan combain, para petani tidak perlu bingung mencari bengkel untuk membetulkan alat tersebut. Pemerintah akan membuat bengkel servis keliling untuk para petani yang ada di Kabupaten Karawang.

5) Tuturan "Aku yakin pasti para petani muda akan terus berkembang, dan anak-anak para petani akan terus meneruskan usaha bapak/ibunya untuk menjadi petani luar biasa."

Pada data (20) termasuk ke dalam gaya bahasa paralelisme karena data tersebut menggunakan bagianbagian kalimat yang mempunyai kesamaan dan pengulangan kata secara berturutan, serta pada kalimat terakhir menggunakan kata sambung, sehingga kesamaan struktur yang digunakan itu secara berturutan membentuk sejajarnya struktur dan mempertegas kalimat dalam tuturan yang digunakan. Dalam hal ini, adanya kesamaan dan kesejajaran pola-pola tersebut mempermudah untuk menemukan gagasan yang disampaikan. Dapat dibuktikan pada tuturan "Aku yakin pasti para petani muda akan terus berkembang, dan anak-anak para petani akan terus meneruskan usaha bapak/ibunya untuk menjadi petani luar biasa." bahwa terdapat dua frasa yang derajat katanya sama. Frasa "petani muda" dapat diartikan generasi muda yang bekerja di ruang lingkup pertanian. Adapun dan frasa "anak para petani" merupakan generasi penerus ibu/bapaknya yang bekerja menjadi petani. Dua frasa tersebut memiliki arti atau makna yang sama, sehingga dapat tergolong ke dalam gaya bahasa paralelisme. Selain itu, ada makna yang terkandung dalam tuturan tersebut, bahwa Bupati Karawang memiliki keyakinan di masa yang akan datang banyak generasi muda yang mau bekerja di sektor pertanian untuk meneruskan orang tuanya.

6) Tuturan "Dan kita harus bergangga bahwa, kebaikan bapak/ibu semuanya memberikan sebulir nasi, ini menjadi kebaikan buat orang banyak."

Pada data (21) termasuk ke dalam gaya bahasa paralelisme karena data tersebut menggunakan bagianbagian kalimat yang mempunyai kesamaan dan pengulangan kata secara berturutan, serta pada kalimat terakhir menggunakan kata sambung, sehingga kesamaan struktur yang digunakan itu secara berturutan membentuk sejajarnya struktur dan mempertegas kalimat dalam tuturan yang digunakan. Dalam hal ini, adanya kesamaan dan kesejajaran pola-pola tersebut mempermudah untuk menemukan gagasan yang disampaikan. Dapat dibuktikan pada tuturan "Dan kita harus bergangga bahwa, kebaikan bapak/ibu semuanya memberikan sebulir nasi, ini menjadi kebaikan buat orang banyak." bahwa terdapat pada kata "kebaikan" yang dituturkan dua kali sehingga mengandung pengulangan pola. Adapun tujuannya yaitu untuk mempertegas kalimat yang menunjukkan adanya fungsi, penekanan, dan gagasan yang dituturkan oleh Bupati Karawang.

Tuturan tersebut tentu memperjelas gagasan yang dimaksud, karenanya gaya bahasa paralelism memiliki keunggulan dalam tuturan. Adapun makna yang terkandung dalam tuturan tersebut, Bupati Karawang berpesan bahwa harus bangga banyak para petani yang mengantarkan berasnya ke Jakarta, banyak para petani para petani yang mengantarkan berasnya ke Bandung. Sehingga bisa menjadikan amal kebaikan untuk warga Karawang, khususnya kepada para petani.

\section{Elipsis}

Terdapat tujuh gaya bahasa elipsis dalam pidato Bupati Karawang. Penulis menjelaskan secara rinci atau memaparkan lebih dalam hasil analisis agar lebih dipahami. Adapun tuturan kalimat gaya bahasa elipsis sebagai berikut. 
3100 Analisis Gaya Bahasa Pidato Bupati Karawang dalam Topik Imbauan serta Rekomendasinya sebagai Materi Pembelajaran Teks Pidato Di MTs - Mimin Widyaningsih, Hendra Setiawan, Ferina Meliasanti DOI: https://doi.org/10.31004/edukatif.v3i5.1208

1) Tuturan "Itu sudah menjadi komitmen kami."

Pada data (21) termasuk ke dalam gaya bahasa elipsis karena data tersebut terjadi penggalan dan penghilangan kata atau kata-kata yang mampu memenuhi bentuk kalimat berdasarkan tata bahasa. Pada tuturan "Itu sudah menjadi komitmen kami." terjadi penghilangan unsur predikat "bagi" setelah kata kerja (verba) "komitmen". Seharusnya tuturan tersebut menjadi "Itu sudah menjadi komitmen bagi kami." Sehingga akan tergolong berdasarkan tata bahasa dalam konstruksi sintaksis. Adapun kata "kami" memiliki arti yang tertuju pada Pemerintah Daerah (Pemda). Makna yang terkandung dalam tuturan tersebut, Bupati Karawang beserta jajaran Pemerintah Daerah (Pemda) memiliki tekad untuk menjadikan Kota Karawang tetap menjadi pusat pertanian terbesar dan menjadi penyokong pertanian untuk ketahanan nasional.

2) Tuturan "Itu menjadi salah satu bentuk komitmen kami."

Pada data (22) termasuk ke dalam gaya bahasa elipsis karena data tersebut terjadi penggalan dan penghilangan kata atau kata-kata yang mampu memenuhi bentuk kalimat berdasarkan tata bahasa. Pada tuturan "Itu menjadi salah satu bentuk komitmen kami." terjadi penghilangan unsur keterangan (adverbial) "sudah" setelah kata pronomina (kata ganti) "itu". Seharusnya tuturan tersebut menjadi "Itu sudah menjadi salah satu bentuk komitmen kami." sehingga akan tergolong berdasarkan tata bahasa dalam konstruksi sintaksis. Adapun kata "kami" memiliki arti yang tertuju pada Pemerintah Daerah (Pemda). Makna yang terkandung dalam tuturan tersebut, Bupati Karawang beserta jajaran Pemerintah Daerah (Pemda) memiliki dua regulasi tentang tata ruang wilayah. Kedua regulasi tersebut yaitu lahan pangan pertanian berkelanjutan dan tentang perlindungan bagi para petani.

3) Tuturan "Makanya saya perlu kerja sama, Pak Hanafi, Pak Kadarisman, teman-teman dinas"

Pada data (23) termasuk ke dalam gaya bahasa elipsis karena data tersebut terjadi penggalan dan penghilangan kata atau kata-kata yang mampu memenuhi bentuk kalimat berdasarkan tata bahasa. Pada tuturan "Makanya saya perlu kerja sama, Pak Hanafi, Pak Kadarisman, teman-teman dinas" terjadi penghilangan unsur predikat kata penghubung "dengan" setelah kata keterangan "kerja sama" dan penghilangan unsur predikat kata penghubung "dan" setelah kata objek "Pak Kadarisman", dan kata keterangan "lainnya". Hal tersebut tergolong berdasarkan tata bahasa dalam konstruksi sintaksis, apabila diubah tuturan kalimatnya menjadi "Makanya saya perlu kerja sama dengan Pak Hanafi, Pak Kadarisman, dan teman-teman dinas lainnya." Makna yang terkandung dalam tuturan tersebut Bupati Karawang menginginkan adanya kerja sama dengan semua anggota pemerintahan terkait pengelolaan regulasi terkair pertanian.

4) Tuturan "Adapun supporting selanjutnya, saya keliling-keliling kemarin."

Pada data (24) termasuk ke dalam gaya bahasa elipsis karena data tersebut terjadi penggalan dan penghilangan kata atau kata-kata yang mampu memenuhi bentuk kalimat berdasarkan tata bahasa. Pada tuturan "Adapun supporting selanjutnya, saya keliling-keliling kemarin." terjadi penghilangan unsur keterangan (adverbia) "sudah" setelah kata subjek "saya". Hal tersebut tergolong berdasarkan tata bahasa dalam konstruksi sintaksis, apabila diubah tuturan kalimatnya menjadi "Adapun supporting selanjutnya, saya sudah keliling-keliling kemarin.” Sehingga mempunyai makna bahwa, Bupati Karawang sudah meninjau persoalan Elsintan pertanian untuk dijaga sebaik mungkin oleh para petani.

5) Tuturan "Akhirnya menjual harganya sangat tinggi."

Pada data (25) termasuk ke dalam gaya bahasa elipsis karena data tersebut terjadi penggalan dan penghilangan kata atau kata-kata yang mampu memenuhi bentuk kalimat berdasarkan tata bahasa. Pada tuturan "Akhirnya menjual harganya sangat tinggi." terjadi penghilangan unsur subjek "dia" dalam tuturan tersebut, sehingga tuturan tersebut berubah kalimat menjadi "Akhirnya dia menjual harganya sangat tinggi." Hal tersebut memiliki makna bahwa Bupati Karawang berpendapat bahwa gabah hasil panen para petani yang dijual kepada oknum-oknum tengkulak, sehingga oknum-oknum tersebut menjual harga gabahnya dengan sangat tinggi. 
3101 Analisis Gaya Bahasa Pidato Bupati Karawang dalam Topik Imbauan serta Rekomendasinya sebagai Materi Pembelajaran Teks Pidato Di MTs - Mimin Widyaningsih, Hendra Setiawan, Ferina Meliasanti DOI: https://doi.org/10.31004/edukatif.v3i5.1208

6) Tuturan "Akhirnya harga kita ancur-ancuran."

Pada data (26) termasuk ke dalam gaya bahasa elipsis karena data tersebut terjadi penggalan dan penghilangan kata atau kata-kata yang mampu memenuhi bentuk kalimat berdasarkan tata bahasa. Pada tuturan "Akhirnya harga kita ancur-ancuran." terjadi penghilangan unsur objek "gabah" dalam tuturan tersebut, sehingga tuturan tersebut berubah kalimat menjadi "Akhirnya harga gabah kita ancur-ancuran." Hal tersebut memiliki makna bahwa Bupati Karawang berpendapat bahwa gabah hasil panen para petani yang dijual kepada oknum-oknum tengkulak, sehingga oknum-oknum tersebut menjual harga gabahnya dengan sangat tinggi dan tidak sebanding dengan harga beli yang ditawarkan kepada para petani.

7) Tuturan "Boleh tepuk tangan lagi, jangan ragu-ragu."

Pada data (27) termasuk ke dalam gaya bahasa elipsis karena data tersebut terjadi penggalan dan penghilangan kata atau kata-kata yang mampu memenuhi bentuk kalimat berdasarkan tata bahasa. Pada tuturan "Boleh tepuk tangan lagi, jangan ragu-ragu." terjadi penghilangan unsur kata subjek. Sehingga mempunyai makna bahwa, Bupati Karawang memperbolehkan tamu yang hadir dalam acara Penyerahan Bantuan Alat dan Mesin Pertanian Rice Miling Unit (RMU) dan Sapi di Dinas Pertanian, untuk memberikan tepuk tangannya.

\section{Gradasi}

Terdapat satu gaya bahasa gradasi dalam pidato Bupati Karawang. Penulis menjelaskan secara rinci atau memaparkan lebih dalam hasil analisis agar lebih dipahami. Adapun tuturan kalimat gaya bahasa gradasi sebagai berikut.

1) Tuturan "Jadi, banggalah menjadi para petani, banggalah menjadi orang Karawang, banggalah hari ini mendapat bantuan dari Bapak Haerudin Amin melalui Bapak Rohman, dan juga pemerintah daerah Kabupaten Karawang."

Pada data (28) termasuk ke dalam gaya bahasa gradasi karena data tersebut mengandung suatu rangkaian atau urutan tiga kata atau istilah yang secara sintaksis bersamaan memiliki satu ciri dan beberapa ciri semantik satu ciri diulang-ulang dengan perubahan-perubahan yang bersifat kuantitatif. Pada tuturan "Jadi, banggalah menjadi para petani, banggalah menjadi orang Karawang, banggalah hari ini mendapat bantuan dari Bapak Haerudin Amin melalui Bapak Rohman, dan juga pemerintah daerah Kabupaten Karawang." data tersebut dapat dibuktikan pada kata "banggalah" terjadi tiga kali pengulangan. Adapun makna yang terkandung bahwa Bupati Karawang memotivasi para tamu yang menghadiri acara Penyerahan Bantuan Alat dan Mesin Pertanian Rice Miling Unit (RMU) dan Sapi di Dinas Pertanian, harus mempunyai rasa bangga hidup di Kota Karawang karena mempunyai ratusan hektare lahan pertanian. Tidak hanya itu, banyak juga para donatur baik itu dari pemerintah daerah maupun pemerintah pusat yang memberikan bantuannya untuk para petani yang ada di Kabupaten Karawang.

\section{Asindeton}

Terdapat tiga gaya bahasa asindeton dalam pidato Bupati Karawang. Penulis menjelaskan secara rinci atau memaparkan lebih dalam hasil analisis agar lebih dipahami. Adapun tuturan kalimat gaya bahasa asindeton sebagai berikut.

1) Tuturan "Industri sudah dipatok, tidak mungkin tambah lagi."

Pada data (29) termasuk ke dalam gaya bahasa asindeton karena data tersebut mempunyai acuan padat, kata, frase, dan klausa yang sederajat tidak dihubungkan dengan kata sambung. Hanya saja, bentuk kalimatnya hanya dipisahkan oleh tanda koma saja. Pada tuturan "Industri sudah dipatok, tidak mungkin tambah lagi." data tersebut menjelaskan secara singkat tanpa adanya kata penghubung, akan mempermudah orang yang menyimak pidato Bupati Karawang dalam mengingat bahwa industri sudah dipatok dan tidak akan bertambah lagi. 
3102 Analisis Gaya Bahasa Pidato Bupati Karawang dalam Topik Imbauan serta Rekomendasinya sebagai Materi Pembelajaran Teks Pidato Di MTs - Mimin Widyaningsih, Hendra Setiawan, Ferina Meliasanti DOI: https://doi.org/10.31004/edukatif.v3i5.1208

2) Tuturan "Ini traktor roda dua kurang lebih tujuh ratus lima puluh buah, traktor roda empat itu sepuluh, pompa enam ratus lima pulu delapan, Hand Sprayer lima ratus lima puluh enam, Transpoter delapan tujuh, Combine sembilan, Cultivator dua puluh enam."

Pada data (30) termasuk ke dalam gaya bahasa asindeton karena data tersebut mempunyai acuan padat, kata, frase, dan klausa yang sederajat tidak dihubungkan dengan kata sambung. Hanya saja, bentuk kalimatnya hanya dipisahkan oleh tanda koma saja. Pada tuturan "Ini traktor roda dua kurang lebih tujuh ratus lima puluh buah, traktor roda empat itu sepuluh, pompa enam ratus lima pulu delapan, hand sprayer lima ratus lima puluh enam, transpoter delapan tujuh, combine sembilan, cultivator dua puluh enam." data tersebut menjelaskan secara singkat tanpa adanya kata penghubung, akan mempermudah orang yang menyimak pidato Bupati Karawang dalam mengingat bahwa ada beberapa alat pertanian yang dimiliki oleh Dinas Pertanian.

3) Tuturan "Adapun hari ini, tentunya melalui Pak Haerudin Amin, melalui Pak Rohman, kita dibantu traktor roda dua ini sepuluh, roda empat delapan, combain lima, sapinya sempat puluh ekor buat dua kelompok, RMU buat penggilingan satu."

Pada data (31) termasuk ke dalam gaya bahasa asindeton karena data tersebut mempunyai acuan padat, kata, frase, dan klausa yang sederajat tidak dihubungkan dengan kata sambung. Hanya saja, bentuk kalimatnya hanya dipisahkan oleh tanda koma saja. Pada tuturan "Adapun hari ini, tentunya melalui Pak Haerudin Amin, melalui Pak Rohman, kita dibantu traktor roda dua ini sepuluh, roda empat delapan, combain lima, sapinya sempat puluh ekor buat dua kelompok, RMU buat penggilingan satu." data tersebut menjelaskan secara singkat tanpa adanya kata penghubung, akan mempermudah orang yang menyimak pidato yang disampaikan oleh Bupati Karawang terkait beberapa bantuan alat atau mesin pertanian, RMU, dan sapi berlangsung di Dinas Pertanian.

\section{Polisindeton}

Terdapat dua gaya bahasa polisindeton dalam pidato Bupati Karawang. Penulis menjelaskan secara rinci atau memaparkan lebih dalam hasil analisis agar lebih dipahami. Adapun tuturan kalimat gaya bahasa polisindeton sebagai berikut.

1) Tuturan "Karena apa, karena ada juga peralihan dari orang tua kita sebagai petani, anaknya rata-rata enggak mau meneruskan usaha bapaknya sehingga perlu mekanisasi, perlu alat, dan ini diperlukan untuk meningkatkan produktivitas pertanian."

Pada data (31) termasuk ke dalam gaya bahasa polisindeton karena data tersebut mempunyai acuan padat, kata, frase, dan klausa yang sederajat serta dihubungkan satu sama lain menggunakan kata sambung. Hanya saja, bentuk kalimatnya hanya dipisahkan oleh tanda koma saja. Pada tuturan "Karena apa, karena ada juga peralihan dari orang tua kita sebagai petani, anaknya rata-rata enggak mau meneruskan usaha bapaknya sehingga perlu mekanisasi, perlu alat, dan ini diperlukan untuk meningkatkan produktivitas pertanian." data tersebut menjelaskan secara singkat dengan adanya kata penghubung "dan" yang menghubungkan klausa dengan klausa. Makna yang terkandung dalam data tersebut adalah peralihan dari orang tua yang bekerja sebagai petani, rata-rata anaknya tidak mau meneruskan usaha bapaknya di sektor pertanian.

2) Tuturan "Program pemerintah daerah untuk membantu para petani kita melalui asuransi pertanian yang dibayar oleh Pemerintah Daerah Kabupaten Karawang melalui APBD."

Pada data (32) termasuk ke dalam gaya bahasa polisindeton karena data tersebut mempunyai acuan padat, kata, frase, dan klausa yang sederajat serta dihubungkan satu sama lain menggunakan kata sambung. Pada tuturan "Program pemerintah daerah untuk membantu para petani kita melalui asuransi pertanian yang dibayar oleh Pemerintah Daerah Kabupaten Karawang melalui APBD." data tersebut menjelaskan secara singkat dengan adanya kata penghubung "yang" digunakan untuk menghubungkan klausa dengan klausa. Makna yang terkandung dalam data tersebut adalah Pemerintah Daerah Kabupaten Karawang menggratiskan dan membantu para petani melalui asuransi pertanian. 
3103 Analisis Gaya Bahasa Pidato Bupati Karawang dalam Topik Imbauan serta Rekomendasinya sebagai Materi Pembelajaran Teks Pidato Di MTs - Mimin Widyaningsih, Hendra Setiawan, Ferina Meliasanti DOI: https://doi.org/10.31004/edukatif.v3i5.1208

Pembelajaran daring atau PJJ (Pembelajaran Jarak Jauh), menjadi hal yang utama dalam pelaksanaan pembelajaran di tengah pandemi Covid-19 ini. Guru harus mengetahui, menguasai, dan memahami aplikasi apa yang tepat untuk digunakan selama PJJ (Pembelajaran Jarak Jauh) berlangsung dianjurkan oleh pemerintah. Berdasarkan hasil penelitian yang telah dilakukan, maka dapat direkomendasikan dalam pembelajaran Bahasa Indonesia dengan pembelajaran berbasis teks. Teks yang dimaksud ialah pidato persuasif, karena dapat dijadikan rujukan bagi guru di MTs. Tujuan impikasinya ialah melalui penggunaan media pembelajaran yang saling terhubung melalui pembelajaran daring dengan menggunakan aplikasi WhatsApp. Pembelajaran teks pidato persuasif dengan menggunakan aplikasi WhatsApp dapat menjadi solusi dalam mentransfer ilmu pengetahuan dari guru terhadap siswanya.

\section{KESIMPULAN}

Berdasarkan penelitian yang dilakukan, dapat disimpulkan bahwa data yang terkumpul berupa data rekaman video pidato Bupati Karawang yang direkam langsung oleh penulis, berdurasi 16 menit lewat 5 detik menggandung gaya bahasa serta mengandung makna sebanyak 35 tuturan. Dalam hal ini, hasil penelitian yang telah dilakukan mengandung 35 tuturan tersebut terbagi ke dalam 9 gaya bahasa, di antaranya: Gaya bahasa metonimia 1 tuturan, gaya bahasa eufemisme 4 tuturan, gaya bahasa antonomasia 4 tuturan, gaya bahasa erotesis 7 tuturan, gaya bahasa paralelisme 6 tuturan, gaya bahasa ellipsis 7 tuturan, gaya bahasa gradasi 1 tuturan, gaya bahasa asindeton 3 tuturan, dan gaya bahasa polisindeton 2 tuturan. Adapun hasil dari penelitian ini, peneliti merekomendasikan untuk pembelajaran Bahasa Indonesia. Rekomendasi tersebut berhasil diterapkan terkait materi teks pidato persuasif dengan menggunakan aplikasi WhatsApp.

\section{UCAPAN TERIMA KASIH}

Puji serta syukur penulis panjatkan ke hadirat Allah SWT, yang senantiasa memberikan rahmat dan hidayah-Nya sehingga penulis bisa menyelesaikan artikel ini. Terima kasih diucapkan untuk kedua orang tua atas doa dan selalu memberikan motivasi yang tiada hentinya. Terima kasih kepada dosen pembimbing Universitas Singaperbangsa Karawang, Bupati Karawang, dan untuk sahabat yang selalu menemani penulis hingga detik ini.

\section{DAFTAR PUSTAKA}

Ardiansyah, F. (2017). Analisis Retorika Basuki Tjahaja Purnama Dalam Kampanye Rakyat Pemilihan Kepala Daerah Khusus Ibukota Jakarta Di Rumah Lembang 2017 (Kajian Retorika Aristoteles). Journal Bapala Unesa, 2017(1), 1-16. Https://Www.Neliti.Com/Publications/243606/Analisis-Retorika-BasukiTjahaja- Purnama-Dalam-Kampanye-Rakyat-Pemilihan-Kepala

Arikunto, S. 2010. Prosedur Penelitian: Suatu Pendekatan Praktik. PT. Rineka Cipta.

AR, Syamsuddin Dan Damaianti, Vismaia S, 2015. Metode Peneltian Pendidikan Bahasa. Cetakan Keenam.

Bandung : Remaja Rosdakarya.

Budiono. 2015. Kamus Lengkap Bahasa Indonesia. Surabaya: Karya Agung.

Bosrowi Dan Suwandi. 2008. Memahami Penelitian Kualitatif. Jakarta: Rineka Cipta

Gustina, Maya. 2015. Gaya Bahasa Pengetahuan Dan Penerapan. Klaten: Intan Pariwara. Keraf, G. 2009. Diksi Dan Gaya Bahasa. Jakarta: Gramedia Pustaka Utama.

Kusumaningrum, Y F. 2014. “Analisis Kritis Teks Pidato Susilo Bambang Yudhoyono Terkait Kenaikan Bbm 
3104 Analisis Gaya Bahasa Pidato Bupati Karawang dalam Topik Imbauan serta Rekomendasinya sebagai Materi Pembelajaran Teks Pidato Di MTs - Mimin Widyaningsih, Hendra Setiawan, Ferina Meliasanti DOI: https://doi.org/10.31004/edukatif.v3i5.1208

Tahun 2012-2013.” Http://Eprints.Undip.Ac.Id/48552/.

Kusumaningrum, Y. F. (2014). Analisis Kritis Teks Pidato Susilo Bambang Yudhoyono Terkait Kenaikan

BBM Tahun 2012-2013. Kusumaningrum, Y F. 2014. "Analisis Kritis Teks Pidato Susilo Bambang Yudhoyono Terkait Kenaikan Bbm Tahun 2012-2013.” Http://Eprints.Undip.Ac.Id/48552/.

Mahsun, M.S, 2012. Metode Penelitian Bahasa, Tahapan Strategi, Metode, Dan Tekniknya. Cetakan Keenam.

Jakarta: Rajagrafindo Persada.

Moleong, L. 2010. Metode Penelitian Kualitatif. Bandung: Remaja Rosda Karya.

Muhammad. 2011. Metode Penelitian Bahasa. Yogyakarta: Ar Ruz Media.

Permendiknas. 2009. Ejaan Bahasa Indonesia Yang Disempurnakan. Yogyakarta: PT Pustaka.

Purangga, H. (2017). Penggunaan Gaya Bahasa Mario Teguh Dalam Instagram. Jurnal Bahasa Dan Sastra, 2(2), 39-48.

Puspita, Ristiana Yani. 2014. Cara Praktis Belajar Pidato, MC, Dan Penyiar Radio. Yogyakarta: Notebook. Setianingsih, Ika. 2019. Ragam Gaya Bahasa. Yogyakarta: Intan Pariwara.

Sudaryanto, 2015. Metode Dan Aneka Teknik Analisis Bahasa. Cetakan Pertama. Yogyakarta: Senata Dharma

University Press.

Sugiyono, 2009. Memahami Penelitian Kualitatif. Bandung: Alfabeta.

Sugiyono, 2016. Metode Penelitian Kuantitatif Kualitatif $R \& D$. Bandung: Alfabeta.

Slamet Y, 2007. Dasar-Dasar Keterampilan Bahasa Indonesia. Surakarta: UNS Press.

Tarigan, H.G. 2013. Pengajaran Gaya Bahasa. Bandung: Angkasa Bandung. 